\title{
OPENNESS OF A UNIVERSITY LIBRARY TO THE PUBLIC AS A KEY FOR FURTHER DEVELOPMENT OF A SOCIETY
}

Tian Yongmei, Wang Xiaodan, Harbin Institute of Technology, tianym@hit.edu.cn, Wangxd@hit.edu.cn

\begin{abstract}
It has been argued for many years that whether the university library should be open to the society or not, not only the university library has the responsibility and ability to be open to the social readers, but also it is the need of making lifelong education and building a Learning Society. Be it whether the experiences from overseas or the development of the university library itself, it is an inevitable trend of keeping sustainable development, thereby enlarging the range of services, maximizing fully our advantages and serving the society in response to actual situation. It is the ultimate solution that government and universities join hands to open the university library service to the community.
\end{abstract}

UDC Number: 304 37.07, DOI: 10.12955/cbup.2013.36

Keywords: university library, service society, opening

\section{Introduction}

In 2007, on the issue of whether the University Library should be open to the public, International Herald Leader and Sina held a joint investigation. The results of the investigation showed that $75.99 \%$ of people were of the opinion that the University Library should be opened to the public ( $\mathrm{Wu}, 2007)$.

The subject, in fact, has been mentioned many times in recent years but the openness of the University Library remained limited (Fudan university library). The public either can only read but cannot borrow the books or can only apply for a temporary library card with a number of charges such as in the Beijing University Library and Tsinghua University Library. So the degree of openness has not been widely recognized by members of the society.

University Library Information Resources are the important part of cultural resources of a nation. The university library, in addition to meet the teaching and research requirements of the university students and teachers, should be open to the general public. Universities are not supposed to monopolize literature resources. The general the public have the due right to benefits from the University Library.

\section{University Library's liberalization to the public is a necessary trend of development}

The country, to build a Learning Society, should provide her citizens the appropriate resources and places to learn. The financial situation of the state and differences in the possession of resources of between the public and university libraries makes it inevitable that university libraries must be open to the general public. 


\section{The situation of the public libraries in China}

According to the staff from the Ministry of Culture, during a fifteen year period, Social and Cultural Division's Library materialized the Two Museum Projects at which the country has basically realized its goals of having "libraries and cultural centers in every county" (Ministry of culture of the People's Republic of China, 2007). The funding for the purchase of books and operations of these libraries has been increased significantly. Nevertheless, in 2006, China's per capita possession of books was 0.39 volumes. In 2006, the National Public Library per capita cost of purchasing books was 0.508 Yuan (Wang, 2007). In 2007, the government funds allocated to public libraries were 3.954 billion Yuan, last year there was an increase up to 7.6 billion Yuan. But due to inflation, the national per capita of books has not increased but the actual cost of purchasing books (CCNT, 2008).

The library has a weak foundation in our country. There is a shortage of financial resources both at local and national level. So there is a gap between the demand and supply. Demand is increasing due to growth in demand for and lack of supply of public cultural services. For instance, due to these financial constraints, cultural operating expenses could develop a lower base in the western region of the country. Though there has been a large increase in cultural spending but the absolute increase in the amount has not proved to be sufficient to break the financial constraint. Thus the western region has been facing cultural debts due to the financial issues. A serious shortage of funds has affected the provision of public culture products and services for the masses. In some places, as a result of relatively poor financing, investment funds to the library are almost zero.

\section{The distribution of financial resources of libraries in our country}

The relevant statistics are evident that, in 2554 colleges and universities of China, there are more than 600 million copies of books (Ministry of Education of the People's Republic of China, 2012) but the public libraries have only 400 million books. University Libraries have $65 \%$ of e-journals whereas the public libraries have only $28.6 \%$ of these. University Library has $30 \%$ of line database but the public library has only $2.9 \%$ of a line database. China's annual procurement volume of the Library cost is nearly 5 billion Yuan. Out of this amount 300 billion Yuan are allocated to University libraries whereas 2 billion Yuan are allocated to the public libraries and special libraries (Pan, 2007). So we can conclude that, in contrast to the university libraries in China, public libraries have a shortage of resources. There college students and school staff add up to 45 million but they only have access to only $60 \%$ percent of the domestic books resources.

There are 35 qualified tertiary institutions in Harbin, and they hold tens of millions of collected resources. But there are very few public libraries. There are only 8 municipal libraries. Harbin City Library has created 50 community libraries from 2006 to the present (About Harbin City Library). The community libraries hold only 25 kinds of newspapers, 40 kinds of publications and more than 3000 books. Government invested 80,000 Yuan start-up capital to each library. Government has provided 30,000 Yuan book-purchasing annually $(\mathrm{Ju}, 2008)$. This meager amount is apparently not enough for population of 4 millions of the city.

A survey was conducted by the author about the university libraries and public libraries in Harbin. The results of survey revealed that there was lack of funds and the amount of books in the public libraries increased very slowly. The librarians, at Harbin Library, found 50\% of books to be leisure books of which less than $30 \%$ were science books. The Harbin Daoli District Library has only about 100 readers on per day. 


\section{The experiences of some foreign university libraries are open to the public}

Most university libraries in developed countries are open to the public. In UK, Cambridge University Library, University Specialty Library and academic departments' libraries all have adopted the 'open-shelf' method to provide services to out-of-school readers. These out-of-school readers need have no need to provide any documents. They can enjoy reading, browsing, Internet access and other services just like the in-school readers. The United States Federal law, according to the Higher Education Act, states that public university libraries are built with taxpayer money, and they may not refuse out-of-school readers. Some famous private universities such as Harvard University, Yale University, also do not refuse to the public and the tourists or visitors. In France, Japan and other developed countries, the university libraries and public libraries have no clear boundaries; out-of-school readers are free to read, however, borrowing books do need a library card (Liu, 2011). These all universities are the backbones in creating a city where all people can read.

Of course, different countries have different situations. The number of colleges and universities of these countries accounted for a higher proportion of their population, while Chinese universities are still at the developing stage. If we catch up with the degree of openness abroad; we have to bear more pressure.

\section{University library should open the door to society}

University library has the responsibility of to be open to society. It is the responsiblity of the system that the public resources such as university liberaries should be open to the community. First of all, the college library and information resources of public culture itself are important parts of the resources and should be available to the entire public for use. Second, a university is a 'temple' of learning, it has an obligation to disseminate scientific and cultural knowledge to enhance social civilization and bring up talents for the society. It also trains social personnel. Third, in view of financial sources, the money of the universities are from taxpayers so the taxpayers have the right to enjoy the public resources.

\section{University library has ability to open to society}

University library has the material resources which are open to the public. University Library has just gone through the assessment of nationwide university undergraduate teaching, many libraries purchased a large number of books, therefore, has reached the target that each student owns 80 books and also to ensure that the library buys 3-4 books for each student per year. Readers, on the other hand, use the diversification of information resources, leading to a decline in book borrowing, resulting in a large number of idle books, especially in the holidays, books and venues are left unused, which is a great waste of resources. Library is an institute that disseminates information resources to service the society, economy and culture. The paper and electronic resources of university libraries are more systematic and professional. The social value of library is truly realized by its value of collected resources, and it plays a better role in its application.

The HIT library, for instance, owns 2,700,000 volumes of traditional stock holdings, 1,750,000 books, more than 900,000 copies of electronic books and more than 5,000 kinds of periodicals, with the introduction of domestic and 51 kinds of large-scale bibliographic databases. HIT has 30,000 full-time 
students. In 2008, the daily average of borrow-volume of all the full-time students was 2527 during the semester, but the daily average of borrow-volume was only 1204 during the holidays. University Library has enough personnel to ensure being open to society. University Library is based on the university itself, the academic structure of its staff is more reasonable and the staff is more professional.

\section{The needs of the community}

If University Library Services are only limited to the full-time students and provide several years of education by stages, then the role of university teaching seems to be too narrow. The learning and education of citizens are both life-long, graduates of university and people who did not pass the entry exam of university and learn the skills after getting a job and research institutes readers have the professional needs for information resources. Libraries should provide continuous education for citizens and life-long education services so that citizens have equal rights to information, in order to build a learning society leading to a solid foundation.

\section{University Library opening is its own need of self-development}

Although universities in China are confronting with some difficulties but, in the long run, there is no doubt that that the university will open its library to the public. The opening of University Library to the society is not only for social services but also for the needs of its own self development.

There is a need to improve the quality of allocation of resources of the University Library and avoid waste of resources. According to statistics, the University Library resource utilization is generally lower than $40 \%$, some less than $20 \%$. At HIT, the quantity of the average book-borrow of each student is not more than 12 volumes, but the actual rate is less than 2 volumes and the borrow-categories are concentrated on the type of teaching reference. On one hand, Library purchases a large number of books to meet the teaching evaluation and library assessment, on the other hand, efficiency in the use of these resources is not satisfactory. Borrowing rate is also an important indicator of teaching evaluation and is difficult to achieve. If the Library opens up to the society, it will be able to access a greater range of feedback that helps to adjust the purchase of types of books and other resources in a timely manner, to serve the readers better.

The web-based database which the University Library annually puts a lot of money into is generally only used in the campus network. Small institutions or individuals could not afford to have this web-based database. Hence, from a social perspective, this too blocks the progress of academic research.

\section{Improve the status of University Library and avoid marginalization}

With the network in-depth of information resources, users gradually understand how easy to use it. Now the OA resources are becoming more and more, and people who try to find information on the network have found that it is becoming more and more convenient. University faculties and libraries ordered a large number of databases, but manual recording of books borrowed by the Library Advisory services are increasingly indifferent to this network usage. Through the way University Library opens to the society, giving full play to the role of its library, will enable the society to have a 
better understanding and more acceptances of universities, which in turn enhance the prestige of universities in the society.

University Library gives full play to the potential of professional and technical personnel. In recent years, due to the improvement of the work nature and status of the University Library, it has gradually build-up professionals of various disciplines and personnel structure is more reasonable. But the benefits of human resources have created the duplication of a single service that is not conducive to play the potential of every member of staff. By opening the library to the society, it helps to enhance the social benefits of human resources and avoid overstaffing.

\section{The demand of University Library could have sustainable development}

With the cause of the prosperity of the Library and the in-depth of the network, the types of readership and needs are also changing. The reader is the basis of the library's existence. But with the emergence of a variety of network libraries which are also streaming our readers: the birth of the Open Content Alliance (OCA); the opening of Microsoft's online library Live Search Books; China's Read Show and The Student and so on, the births of a series of public services and commercial products are weakening the role of the library. The outsourcing of traditional business of library to business companies reduces the value of the existence of the library from inside.

Government and University join hands to serve the society strengthen the legislative and administrative support. Foreign University Library is able to successfully carry out society service; it has something to do with a sound legal system. As early as 1920, the United States formulated the Library Law to protect the legitimacy of the library survival and continuity (The Encyclopedia Americana, 1920). In 1996, the U.S. government also issued the Library Services and Technology Act, whose main objectives were: promoting the construction of the network between the libraries as well as educational institutions (ALA). LSTA is a United States federal library grant program. Its roots come from the Library Services Act that was first enacted in 1956 (Gregory, 1999). In China, the Library Law of People's Republic of China has started in 2001 (Liu, 2003), but until now it is still at the developing stage (Yan \& Ma, 2010). There is no law to regulate the co-ordination work of government departments at all levels of sector, which is essential, and to purchase the resources and allocate the funds to the overall situation. According to their own conditions, universities choose the appropriate way to serve the society. University Library should estimates its own ability, does a self-assessment before opening up, and cannot rush into its opening to the public. It is also necessary to have full understanding and analysis about the following: the needs of inside-school readers, the book borrowing rate of the inside-library readers, possession of books per capita, the quantity of idle books and seats within the reading rooms, and the application of digital resources. So long as these things are finished, then we would choose the most appropriate entry point and do a better job. Produced by the Google Docs online questionnaire collected 1521 valid receipts, which Open University Library's most respected aspects: it is open for different reader groups. University's resources constitutes mainly for the teaching and research of school. Their focuses on aspects of data collection are different, system resources focused mainly on academic, research, and reference-based resources. It is feasible to open to the staff of universities, research institutions and organization, and then gradually open up to the public. This is also a two-way choice between the library and reader, at the same time reduces the pressure brought about by opening the library to the public. 
Whereas many libraries complained about shortage of seats in the reading room, we can try by opening in stages and periods. For example, open during the night or during holidays.

Functions of University library are becoming more diverse day by day. Library sets up exhibitions, seminars, special services, provide literature information and technology consulting services as well as cultural activities. University libraries should guide the general public to access to knowledge and become a base for training information technology talents, a place for research and communication, and with its advantage of information collection, organization and retrieval of the library, hold special seminars regularly and provide a variety of professional information and network services for the public. After increasing the social function, it is necessary to adjust the gradual process; to open by steps and levels is more suitable.

\section{Conclusion}

The positive effect of the fact that university libraries are open to the public is indubitable. This openness enables full use of social resources, achieving the popularity of library science and culture and promoting the role of information dissemination. This is a good thing to both society and universities. Universities and society will be a win-win thing. Whether the library is large or small, it can serve society by using its advantages directly while doing a good job for their teaching and research services; make its own contribution to the creation of our bookishness kingdom.

\section{References}

Harbin City Library. (2012). Hā'ěrbīn shì túshū guăn jiănjiè [About Harbin City Library]. (n.d.). Retrieved March 20, 2013, from http://www.hrblib.net.cn:8105/gqfm/gqjs/index.html

ALA. (2013). Library Services and Technology Act (LSTA). Retrieved March 10, 2013, from http://www.ala.org/advocacy/advleg/federallegislation/lsta

CCNT. (2008). Rénjūn wénhuà shìyè fèi 15.04 Yuán [15.04 yuan per capita cultural Operating Expenses]. Retrieved March 13, 2013, from http://www.ccnt.gov.cn/sjzz/jhcws/cwswhtj/ 200805/t20080529_54661.html

Fudan university library. (2013) (n.d.) Túshū jiè hái [Book circulation]. Retrieved March 10, 2013, from http://www.library.fudan.edu.cn/main/list/202-1-20.htm

Gregory, G. (1999). The Library Services and Technology Act: How Changes from LSCA are Affecting Libraries. America Public Libraries, 38, 378-82.

Ju, H. M. (2008). Shèqū túshū guăn wénhuà zhǒngzǐ sā măn chéng jiā jiā ménkǒu piāo shūxiāng [Community libraries spread across city so every family can reach them easily]. Retrieved March 13, 2013, from http://harbin.dbw.cn/system/2008/08/18/051447182.shtml

Liu, X. Q. (2003). On the Progress, Perspective and Contents Concerning The Library Law of the People's Republic of China. China Journal of academic libraries, 21, 2-5.

Liu, Y. H. (2011). Social Services of Academic Libraries in U. S. A.: Reality and Inspirations. China Library and Information, 2, 93-97. 
Ministry of Education of the People's Republic of China. (2012, June,). 2012 Nián jùyǒu pǔtōng gāoděng xuélì jiàoyù zhāoshēng zīgé de gāoděng xuéxiào míngdān [Regular higher academic education enrollment eligibility list of institutions of higher learning in 2012]. Retrieved March 10, 2013, from http://www.moe.edu.cn/publicfiles/business/htmlfiles/moe/moe_634/201206/137993.html

Ministry of culture of the People's Republic of China. (2007). 2007 Nián wénhuà bù xībù kāifā gōngzuò zǒngjié [The development of the western region summary of the work of the Ministry of Culture in 2007]. Retrieved March 11, 2013, from http://www.ccnt.gov.cn/sjzz/shwhs/ wenrwh/200711/t20071130_48863.html

Pan, J. H. (2007). The advantage of University Press to enter the distribution market. China University Publishing, 3, 42-44.

Peking university library. (2013) (n.d.) Běijīng dàxué túshū guăn xiàowài dúzhě jiēdài bànfă [The Peking university library collections borrow system]. Retrieved March 10, 2013, from http://lib.pku.edu.cn/portal/fw/rgzn/guizhangzhidu/notice15

Library Laws and Legislation in the United States. (2013). In The Encyclopedia Americana (1920), Retrieved March 13, 2013, from http://en.wikisource.org/wiki/The_Encyclopedia_Americana_ (1920)/Library_Laws_and_Legislation_in_the_United_States

Tsinghua university library. (2013) (n.d.) Xiào túshū guăn línshí jiè shū zhèng hé yuèlăn zhèng guănlǐ bànfă [Tsinghua university library card, library card management approach]. Retrieved March 10, 2013, from http://lib.tsinghua.edu.cn/service/circulation/tempcard.html

Wang, H. B. (2007, May 19). Wǒguó rénjūn cángshū 0.39 Cè [China's per capita collections 0.39]. Retrieved March 13, 2013, from Xinhuanet http://news.xinhuanet.com/mrdx/2007-05/19/ content_6122177.htm

Wu, L. (2007, Jul 23). Qī chéng y̌̌shàng wăngyǒu rènwéi gāoxiào túshū guăn yīnggāi duìwài kāifàng [More than $70 \%$ of users believe that the university library could be opened for all]. Retrieved March 11, 2013, from http://news.xinhuanet.com/herald/2007-07/23/content_6415174.htm

Yan, Z. Y. \& Ma, X. L. (2010). Thoughts of Accelerating the Process of Library Career Legislation. Library Work in Colleges and Universities. 30, 23-26. 